\title{
Ore Microscopy and Microanalysis of the Nickeliferous Iron Ores from Komnina Vermion Area (N.W. Greece)
}

\author{
Georgios Alevizos, Eftychia Repouskou \\ Department of Mineral Resources Engineering, Technical University of Crete, Chania, Greece \\ E-mail:alevizos@mred.tuc.gr \\ Received May 6, 2011; revised June 29, 2011; accepted July 7, 2011
}

\begin{abstract}
Nickel laterites are considerable sources of nickel. To be successfully exploited it is important to know the mineralogical and microstructural characteristics of the ore. Besides, the identification of the mineralogical components as well as the fabric description, can lead to the interpretation of the mechanism of deposit genesis. The aim of the present study is the microscopic and microanalytical investigation of the Fe-Ni ores from Komnina Vermion area (N.W. Greece). The mineralogical composition of the ore is mainly hematite, quartz, chromite and chlorite, while in minor quantities goethite, nickeliferous chlorite, serpentine, talc and calcite are also present. The ore structure is allotriomorphic inequigranular and the texture is oolitic-pisolitic. According to microscopic examination the deposit can be registered as a secondary pseudo-autochthonous.
\end{abstract}

Keywords: Ore Microscopy, Microanalysis, Fe-Ni-Ores, Komnina-Vermion (Greece)

\section{Introduction}

Nickel laterites constitute a significant proportion of world nickel reserves. About $60 \%$ of the current worldwide production of nickel is derived from sulphide ores and the rest comes from nickel laterites [1]. However, about $70 \%$ of the nickel reserves are present in laterite deposits [2]. As a result, there is growing interest in improving the technology for extraction of nickel and cobalt from laterites, as the demand for stainless steel continues to grow and the sulphide deposits become depleted [3]. Greece is the only EU country with extensive but low-grade nickel laterites. They mainly occur as limonitic laterites and, to a lesser extent, as serpentinic laterites. Nickeliferous limonite is comprised of nickel bearing ferric oxides in deposits formed from ultrabasic rocks. The Greek laterites are unique in the world in that they are sedimentary and have originated by transportation and sedimentation of laterite-derived material, generated by weathering of ultramafic rocks [4]. The Greek laterites are exploited by the nickel producing company LARCO GMMAE, which is the most important metallurgical company in producing Fe-Ni alloy in Greece. The company mines the domestic deposits of Agios Ioannis, Evia and those in Kastoria as well as the Bitincka deposit in Albania. The small Ni concentrations in these ores in combination with the $\mathrm{Ni}$ frequently changing prices, has as result the continuous research of the LARCO company for the positioning of new exploitable ores as well as the optimization of the mineral processing methods. Now days the company's interest is focused on the evaluation of $\mathrm{Fe}-\mathrm{Ni}$ ores in the West Macedonia region (Greece), where considerable occurrences exist for future exploitation. The main $\mathrm{Fe}-\mathrm{Ni}$ deposit is laid at Komnina area in Vermio Mountain [5]. The deposit is located in the west side of Vermio and it is exposed along $3 \mathrm{~km}$ with mean thickness of $6 \mathrm{~m}$. The Fe-Ni ore occurs in the form of parallel beddings with siliceous intercalations over to ultramafic rocks (serpentinites) and it is covered by Kenomanian carbonate conglomerates (Figure 1). The certain feature of the Ni-laterites of Vermio is the presence of a saprolite zone, which is exposed between the serpentinized peridotite and the overlying Fe-Ni ore [6]. The saprolitic layers due to their higher Ni content are commonly treated pyrometallurgically, resulting in the production of either ferronickel or matte [7]. This paper presents the results of the characterization of the Fe-Ni ores by means of optical microscopy and microanalysis.

\section{Materials and Methods}

Detailed mineralogical investigation through reflected light microscopy is a critical part of any study of an ore 


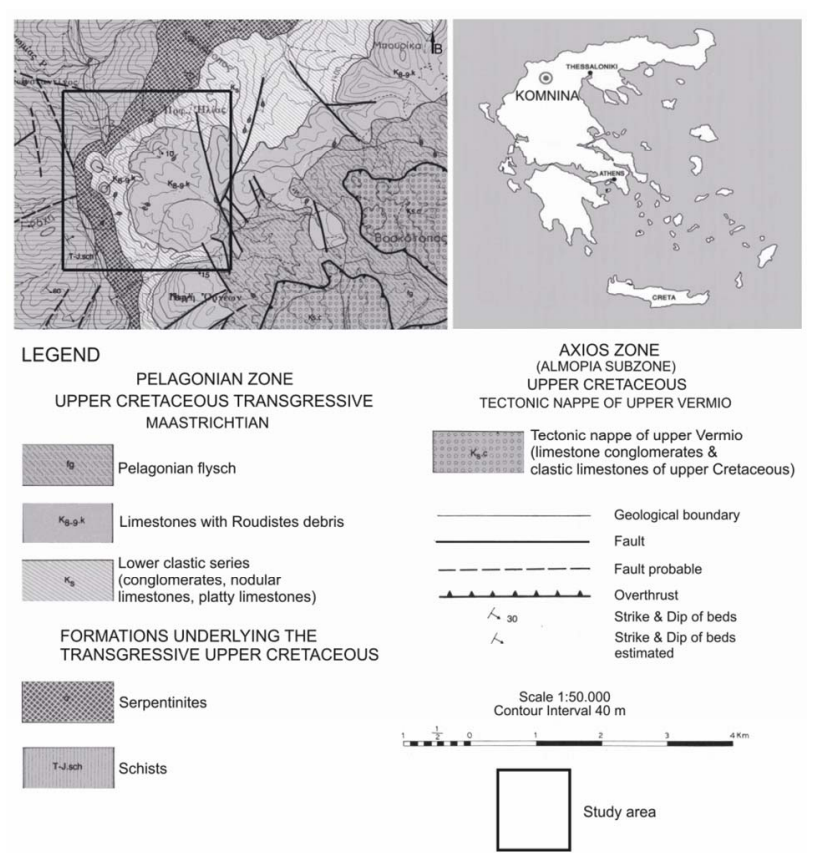

Figure 1. Modified geological map of the study area [8].

deposit. For the identification and interpretation of the Fe-Ni ore mineral associations and textures, polished sections of samples were made and studied under reflected light optical microscope (JENALAB). Mineralogical characteristics of these samples have been investigated with reference to the mineral phases identification and elemental composition by using scanning electron microscopy-backscattered electron images (JEOL model JSM 5400), and microanalyses by energy-dispersive X-ray spectrometry (EDS-OXFORD with software INCA ENERGY 300). The analyses performed using an accelerating voltage $20 \mathrm{KV}$ and beam current approximately $5 \mathrm{nA}$. The reference standards for the microanalysis were provided by MAC ltd. X-ray diffraction technique is also used for certifying the different mineral phases (XRDSIEMENS, D-500, with graphite monochromator).

\section{Results and Discussion}

The Fe-Ni ore is developed over ultramafic rocks (serpentinites), which according to XRD analysis consists mainly of serpentine, talc and in minor amounts of goethite, chromite and calcite. On the contact with the ore, an alteration zone (saprolite zone) exists, with dominant mineral talc, while quartz and calcite are present as secondary components. These saprolite zones indicate that water moved downward to a very low water table [9]. The calcite, in a form of veinlets, is of epigenetic origin.

The Fe-Ni ore is characterized as a sequence of mas-sive ore zones with or without pisolites, quartzitic con-

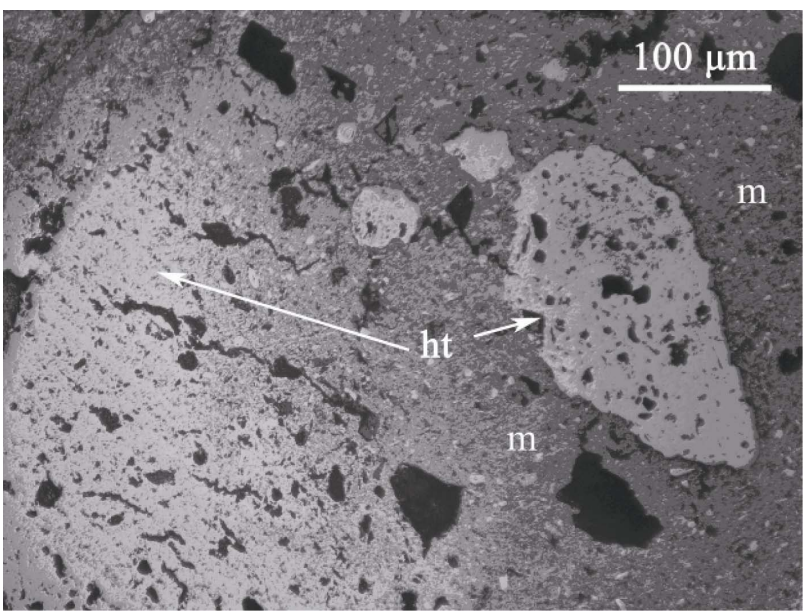

Figure 2. Hematite replaces the groundmass between the grains. (ht $=$ hematite, $m=$ groundmass). Sample S4, Reflected light, // Nicols.

Table 1. EDS microanalyses of mineral phases in ironnickel ores: Hematite (Pisolithes).

\begin{tabular}{ccccc}
\hline Sample & S6 & S6 & S9 & S9 \\
\hline $\mathrm{SiO}_{2}$ & 1.63 & 1.35 & 6.75 & 5.27 \\
$\mathrm{TiO}_{2}$ & 0.19 & 0.24 & 0.41 & 0.55 \\
$\mathrm{Al}_{2} \mathrm{O}_{3}$ & 1.79 & 1.37 & 5.04 & 4.10 \\
$\mathrm{Cr}_{2} \mathrm{O}_{3}$ & 1.92 & 1.91 & 2.23 & 2.23 \\
$\mathrm{FeO}^{\mathrm{a}}$ & 93.56 & 94.28 & 81.24 & 83.92 \\
$\mathrm{MnO}$ & - & - & 0.90 & 0.88 \\
$\mathrm{MgO}$ & 0.91 & 0.85 & 1.50 & 1.60 \\
$\mathrm{NiO}$ & - & - & 1.94 & 1.46 \\
Total $^{\mathrm{b}}$ & 100.00 & 100.00 & 100.01 & 100.01 \\
\hline
\end{tabular}

a. Fe quoted as FeO; b. The total of oxides is normalized to 100 .

glomerate layers and silicified beds on the contact of the underlying ultrabasic rock. The microscopic analysis of the silicified zone shows massive quartz and coarse crystalline quartzitic aggregates. Also hematite of secondary origin, which replaces the binder between the quartzitic grains, is observed (Figure 2). X-Ray Diffraction analysis of this layer showed among others the presence of nickeliferous chlorite (Figure 3). Nickeliferous chlorite has been reported as a mineral constituent of sedimentary nickeliferous iron ores of Greece [10]. Pisolites in various sizes are dispersed in the massive ore layers. These pisolites are determined mainly as peloids but there are also ooids or pisoids as well as complex spheroids. Their mineralogical composition is mainly hematite (Table 1) and partly chlorite. The chlorite presence has a result the change of optical characteristics of hematite. Hematite is often leached from grain surface, whereas the internal texture (concentric laminae) of ooids and pisoids are preserved (Figure 4). The complex spheroids often exceed $3 \mathrm{~mm}$ in size and they have inclusions of clastic grains of chromite, quartz and rarely peloids and ooids (Figure 5). Chromite clastic grains, observed through the binder material, have surfaces generally fractured due to 


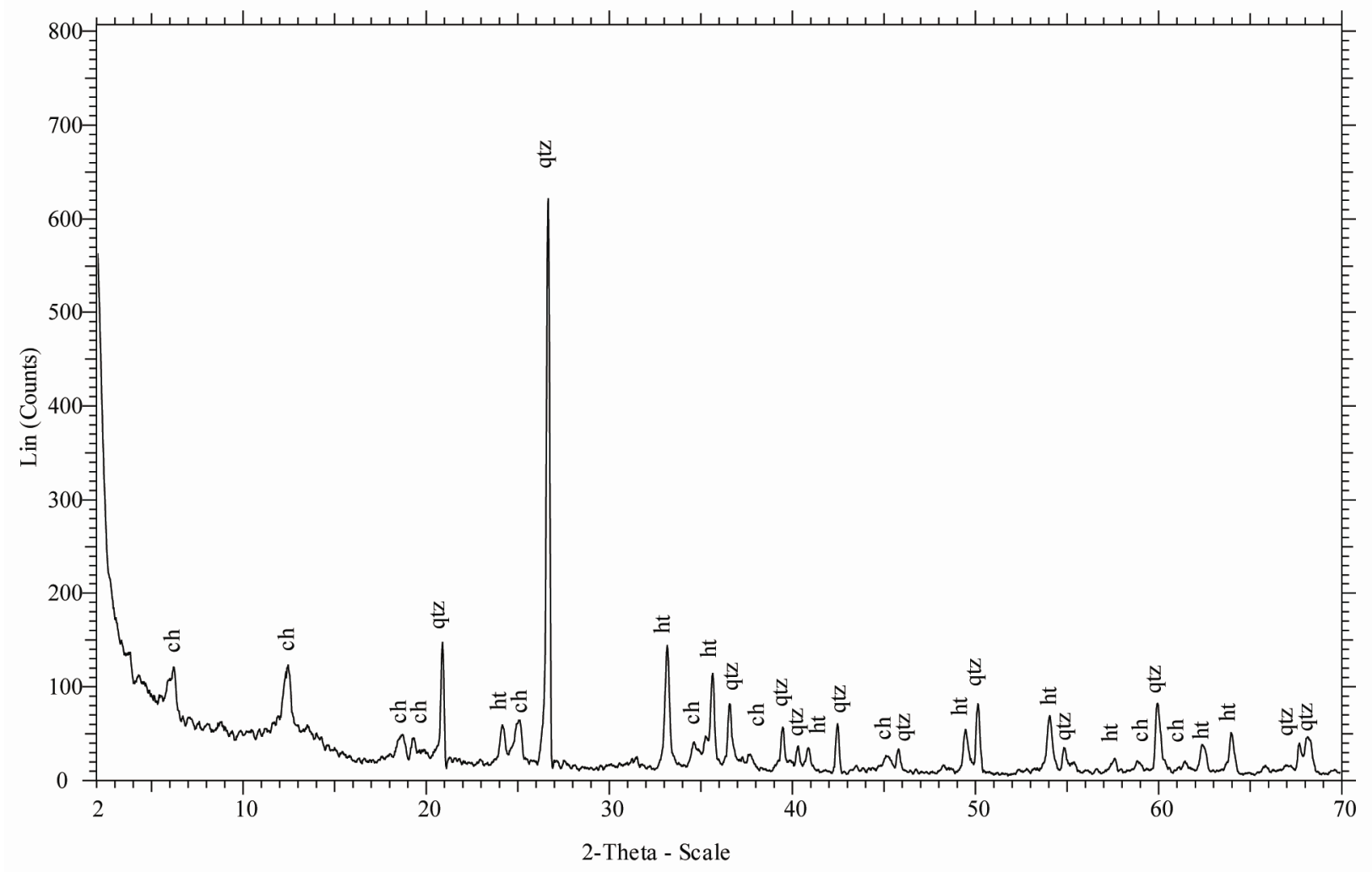

Figure 3. X-ray diffraction pattern of the ore. $(q t z=$ quartz, ht $=$ hematite, ch $=$ nickeliferous chlorite $)$.

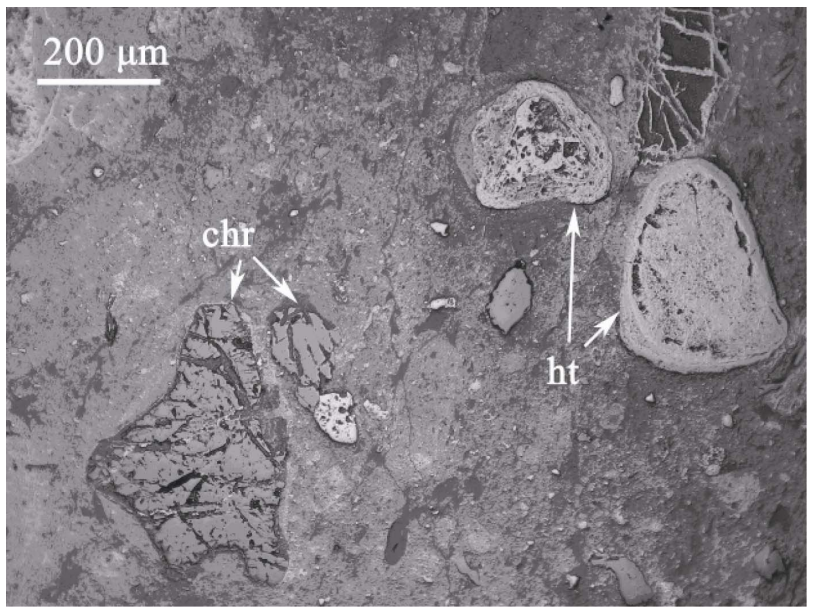

Figure 4. Chromite clastic grains and leached hematite ooid and peloid. (ht $=$ hematite, chr $=$ chromite). Sample $\mathrm{S6}$, Reflected light, // Nicols.

tectonic deformation (cataclastic texture) (Figures 6, 7 and Table 2). A remarkable feature of zoned chromite grains from Vermio Ni-laterite deposits is the presence of ferrian-chromite [11]. The binder material between the grains consists mainly of nickeliferous chlorite. The $\mathrm{Ni}$ contents in the nickeliferous chlorite ranging between 3.07 and $5.26 \mathrm{wt} \% \mathrm{NiO}$ (Table 3). In the massive Fe-Ni

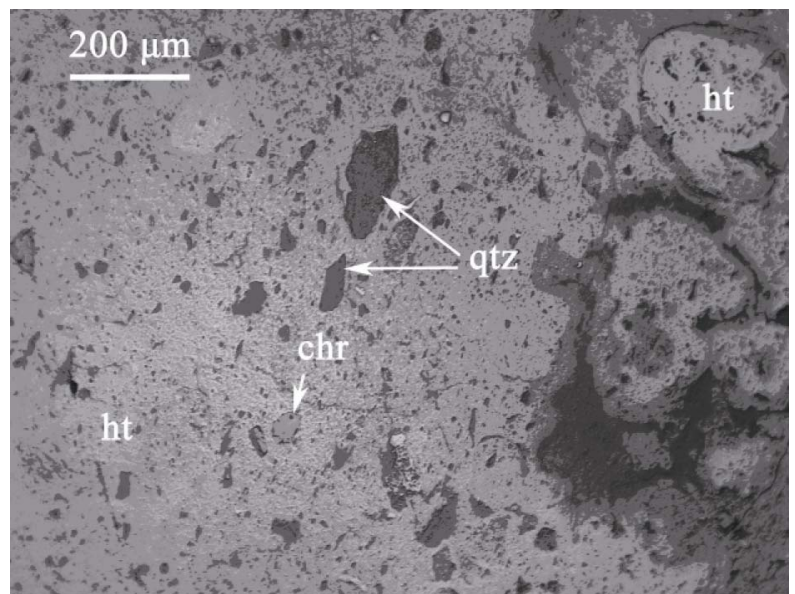

Figure 5. Complex spheroid including hematite peloids, chromite and quartz clastic grains. (ht = hematite, chr = chromite, qtz = quartz). Sample S6, Reflected light, $/ /$ Nicols.

ore zone which is free of spheroids particles, hematite formed as fine grained aggregates and replaces gradually the chloritic binding material, resulting to an epigenetic ferruginisation (Table 4).

The Upper Horizon of the ore consists of intercalations of $\mathrm{Fe}-\mathrm{Ni}$ ore and limestone conglomerate. In this layer within the binder a number of complex spheroids 


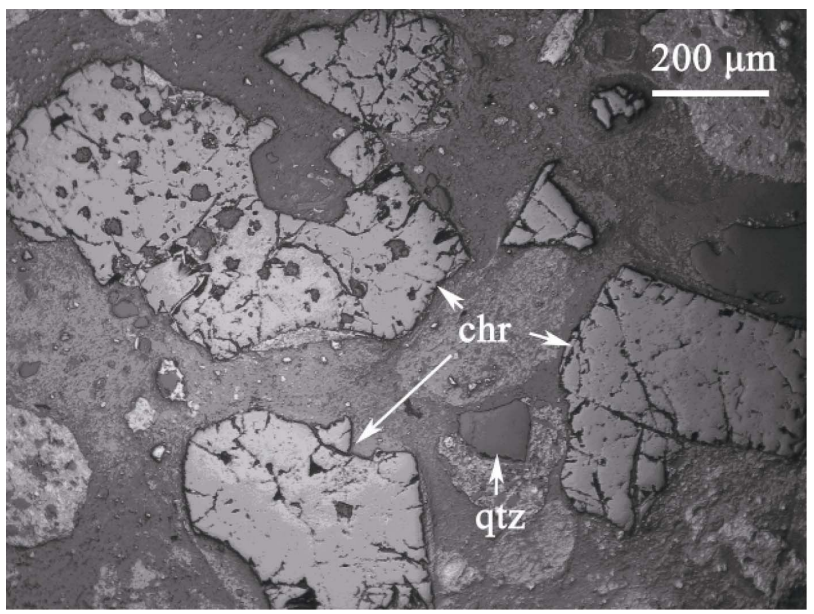

Figure 6. Chromite clastic grains with cataclastic texture and quartz. $(\mathrm{chr}=$ chromite, $q \mathrm{qtz}=$ quartz $)$. Sample S6, Reflected light, // Nicols.
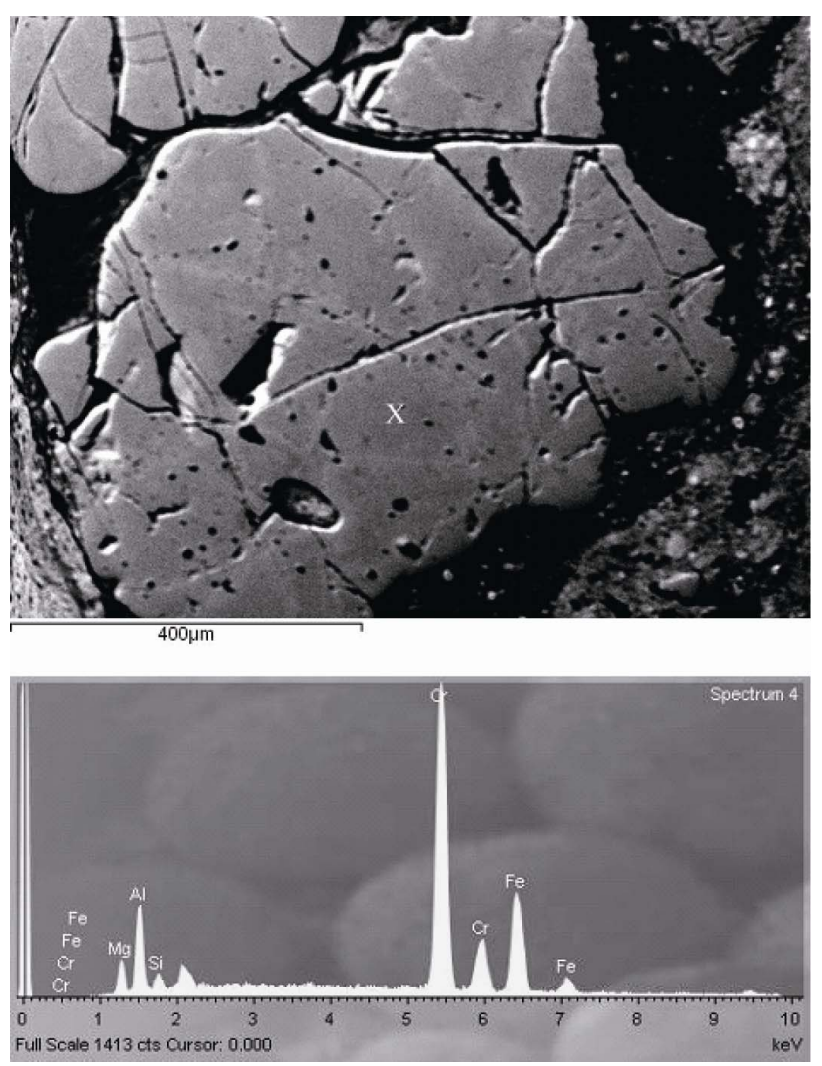

Figure 7. Back scattered image of chromite (SEM) and EDS analysis. Sample S6.

with chromite inclusions as well as, clastic grains of chromite and hematite, is observed. Hematite in the form of secondary ferruginisation replaces progressively the binder between the grains. Generally the ore is characterized by an allotriomorphic inequigranular structure and an oolitic-pisolitic texture.
Table 2. EDS microanalyses of mineral phases in ironnickel ores: Chromite.

\begin{tabular}{ccccc}
\hline Sample & $\mathrm{S} 6$ & $\mathrm{~S} 6$ & $\mathrm{~S} 6$ & $\mathrm{~S} 6$ \\
\hline $\mathrm{SiO}_{2}$ & 0.65 & 0.70 & - & - \\
$\mathrm{Al}_{2} \mathrm{O}_{3}$ & 15.91 & 12.72 & 17.05 & 15.97 \\
$\mathrm{Cr}_{2} \mathrm{O}_{3}$ & 53.99 & 56.75 & 55.34 & 54.89 \\
$\mathrm{FeO}^{\mathrm{a}}$ & 22.34 & 25.10 & 20.46 & 20.43 \\
$\mathrm{MgO}$ & 7.11 & 4.73 & 7.15 & 8.71 \\
$\mathrm{Total}^{\mathrm{b}}$ & 100.00 & 100.00 & 100.00 & 100.00 \\
$\mathrm{Number}$ of ions calculation based on & 32.00 anions per formula \\
$\mathrm{Si}$ & 0.17 & 0.19 & - & - \\
$\mathrm{Al}$ & 4.89 & 4.02 & 5.21 & 4.88 \\
$\mathrm{Cr}$ & 11.13 & 12.04 & 11.33 & 11.25 \\
$\mathrm{Fe}$ & 4.87 & 5.63 & 4.43 & 4.43 \\
$\mathrm{Mg}$ & 2.76 & 1.89 & 2.76 & 3.37 \\
$\mathrm{Total}$ & 23.82 & 23.77 & 23.73 & 23.93 \\
\hline
\end{tabular}

a. Fe quoted as FeO; b. The total of oxides is normalized to 100 .

Table 3. EDS microanalyses of mineral phases in ironnickel ores: Nickeliferous chlorite.

\begin{tabular}{ccccc}
\hline Sample & $\mathrm{S} 6$ & $\mathrm{~S} 6$ & $\mathrm{~S} 6$ & $\mathrm{~S} 6$ \\
\hline $\mathrm{SiO}_{2}$ & 19.61 & 29.29 & 25.56 & 29.48 \\
$\mathrm{Al}_{2} \mathrm{O}_{3}$ & 12.05 & 18.41 & 15.34 & 19.45 \\
$\mathrm{Cr}_{2} \mathrm{O}_{3}$ & 1.14 & 1.12 & 1.27 & 1.04 \\
$\mathrm{FeO}^{\mathrm{a}}$ & 39.01 & 15.03 & 21.48 & 13.91 \\
$\mathrm{MnO}$ & 0.56 & 0.33 & 0.47 & 0.44 \\
$\mathrm{MgO}$ & 12.22 & 18.55 & 15.37 & 17.34 \\
$\mathrm{CaO}$ & 0.61 & 0.65 & 0.51 & 0.43 \\
$\mathrm{NiO}$ & 3.07 & 4.30 & 4.38 & 5.26 \\
$\mathrm{Total}$ & 88.27 & 87.68 & 84.38 & 87.35 \\
$\mathrm{Number}$ of ions calculation based on 28.00 anions per formula \\
$\mathrm{Si}$ & 4.72 & 5.98 & 5.72 & 6.02 \\
$\mathrm{Al}$ & 3.42 & 4.43 & 4.05 & 4.68 \\
$\mathrm{Cr}$ & 0.22 & 0.18 & 0.23 & 0.17 \\
$\mathrm{Fe}$ & 7.85 & 2.57 & 4.02 & 2.38 \\
$\mathrm{Mn}$ & 0.11 & 0.06 & 0.09 & 0.08 \\
$\mathrm{Mg}$ & 4.38 & 5.65 & 5.13 & 5.28 \\
$\mathrm{Ca}$ & 0.16 & 0.14 & 0.12 & 0.09 \\
$\mathrm{Ni}$ & 0.59 & 0.71 & 0.79 & 0.86 \\
$\mathrm{Total}$ & 21.45 & 19.72 & 20.15 & 19.56 \\
\hline
\end{tabular}

a. Fe quoted as FeO.

Table 4. EDS microanalyses of mineral phases in ironnickel ores: Hematite (Matrix).

\begin{tabular}{ccccc}
\hline Sample & S9 & S9 & S9 & S9 \\
\hline $\mathrm{SiO}_{2}$ & 9.38 & 7.35 & 13.19 & 7.61 \\
$\mathrm{TiO}_{2}$ & 0.31 & 0.47 & - & 0.27 \\
$\mathrm{Al}_{2} \mathrm{O}_{3}$ & 6.02 & 6.62 & 9.79 & 6.14 \\
$\mathrm{Cr}_{2} \mathrm{O}_{3}$ & 1.69 & 1.13 & 1.53 & 1.35 \\
$\mathrm{FeO}^{\mathrm{a}}$ & 80.02 & 82.35 & 69.62 & 80.64 \\
$\mathrm{MnO}$ & - & 0.70 & 0.66 & 0.69 \\
$\mathrm{MgO}$ & 2.00 & - & 2.57 & 1.82 \\
$\mathrm{~K}$ & 0.59 & 0.47 & 0.80 & 0.42 \\
$\mathrm{NiO}$ & - & 0.90 & 1.83 & 1.05 \\
$\mathrm{Total}^{\mathrm{b}}$ & 100.01 & 99.99 & 99.99 & 99.99 \\
\hline
\end{tabular}

a. Fe quoted as FeO; b. The total of oxides is normalized to 100 .

\section{Conclusions}

The microscopic investigation combined with the X-ray analysis and the microanalyses of the examined $\mathrm{Fe}-\mathrm{Ni}$ ore, showed the mineralogical composition and the ore fabric, which revealed the genetic process from its for- 
mation up to its final deposition. Thus, the presence of chromite clastic grains inclusions indicates that allochthonous pisolitic material was transported to adjacent formations, deposited and resedimented over the ultrabasic rocks, along with the clastic chromite grains and quartzitic fragments. According to these ore structure characteristics the deposit can be described as a secondary pseudo-autochthonous.

\section{References}

[1] S. Sudol, “The Thunder from down under: Everything You Wanted to Know about Laterites but Were Afraid to Ask,” Canadian Mining Journal, August 2005.

[2] A. D. Dalvi, W. G. Bacon and R. C. Osbourne, "The Past and the Future of Nickel Laterites,” PDAC International Convention, The Prospectors and Developers Association of Canada, Toronto, 2004, p. 27.

[3] R. G. McDonald and B. I. Whittington, "Atmospheric Acid Leaching of Nickel Laterites Review, Part I. Sulphuric Acid Technologies," Hydrometallurgy, Vol. 91, No. 1, 2008, pp. 35-55. doi:10.1016/j.hydromet.2007.11.009

[4] S. L. Agatzini, I. G. Zafiratos and D. Spathis, "Beneficiation of a Greek Serpentinic Nickeliferous Ore, Part I. Mineral Processing,” Hydrometallurgy, Vol. 74, No. 3-4, 2004, pp. 259-265.

[5] A. Apostolikas, E. Frogoudakis and K. Maglaras, "Nickeliferous Deposits in West Macedonia. Present and future Potential," 1st Congress of Economic Geology, Mineral- ogy and Geochemistry Committee, Kozani, Greece, 2000, pp. 25-34 (in Greek).

[6] D. G. Eliopoulos and M. Economou-Eliopoulos, "Geochemical and Mineralogical Characteristics of Fe-Ni- and Bauxitic-Laterite Deposits of Greece,” Ore Geology Reviews, Vol. 16, No. 1-2, 2000, pp. 41-58. doi:10.1016/S0169-1368(00)00003-2

[7] A. E. M. Warner, C. M. Diaz, A. D. Dalvi, P. J. Mackey and A. V. Tarasov, "JOM World Nonferrous Smelter Survey, Part III: Nickel Laterite,” Journal of Metals, Vol. 58, No. 4, April 2006, pp. 11-20.

[8] J. H. Brunn, “Geological Map of Greece,” Scale 1:50000, Pyrgoi Sheet. Institute of Geology and Mineral Exploration, Athens, 1982.

[9] N. Skarpelis, "Lateritization Processes of Ultramafic Rocks in CRETACEOUS Times: The Fossil Weathering Crusts of MAINLAND GReece," Journal of Geochemical Exploration, Vol. 88, No. 1-3, 2006, pp. 325-328. doi:10.1016/j.gexplo.2005.08.066

[10] N. Skarpelis, "Lateritic Weathering Crusts as a Source of Ferruginous Spheroidal Particles of Sedimentary Nickeliferous Iron Ores, Greece," Bulletin T. CXIX de l' Académie Serbe des Sciences et des Arts, Classe des Sciences mathématiques et naturelles, Science naturelles, Vol. 39, 1999, pp. 213-224.

[11] M. Economou-Eliopoulos, "Apatite and Mn, Zn, CoEnriched Chromite in Ni-Laterites of Northern Greece and Their Genetic Significance,” Journal of Geochemical Exploration, Vol. 80, No. 1, 2003, pp. 41-54. doi:10.1016/S0375-6742(03)00181-X 